\title{
OCUPAÇÕES URBANAS:
}

\author{
A POÉTICA TERRITORIAL DA POLÍTICA
}

\section{URBAN OCCUPATIONS:}

THE TERRITORIAL POETICS OF POLITICS

\author{
Natália Lelis \\ Universidade Federal de Minas Gerais, Programa de Pós-Graduação em Geografia, \\ Belo Horizonte, MG, Brasil
}

R E S U M O : Este trabalho propõe uma reflexão sobre as recentes ocupaçôes urbanas organizadas da Regiáo Metropolitana de Belo Horizonte. Ele procura explorar conflitos e contradiçôes que envolvem a constituição e a dinâmica cotidiana desses espaços, tendo como contribuições teóricas principais alguns conceitos de Rancière e de Lefebvre. Defendemos que a própria constituição deles é poiesis política e que o seu cotidiano, marcado por contradiçóes, heterogeneidades e conflitos, aponta para a impossibilidade da política como ordem instituída. Além disso, como espaços diferenciais escavados no espaço abstrato, essas ocupações se tornam espaços do que difere e do que não difere, bem como do conflito entre ambos. Elas se inscrevem no movimento de produção-reprodução que muda e repete o cotidiano da metrópole. Com isso, recolocam a questão da possibilidade do planejamento em relação ao que é efetivamente político.

P A L A V R A S - C H A V E : ocupaçôes urbanas organizadas; política; espaço diferencial; conflitos fundiários urbanos; Rancière; Lefebvre.

A B S T R A C T : The proposal of the present article is to reflect on the recent organized occupations in the Metropolitan Region of Belo Horizonte. It seeks to explore the conflicts and contradictions that involve the constitution and everyday dynamics of these spaces, for which the main theoretical contributions are taken from some concepts of Rancière and Lefebvre. We argue that their very constitution is political poiesis, and that their everyday life, marked by contradictions, heterogeneities and conflicts, indicates the impossibility of politics as an instituted order. Moreover, as differential spaces excavated in abstract space, they become a space of what differs, of what does not differ, and of the conflict that exists between them. They are part of the production-reproduction movement that changes and repeats the everyday life of the metropolis. With this, they reinsert the question on the possibility of planning in relation to what is effectively political.

K E Y W O R D S : organized urban occupations; politics; differential space; urban land conflicts; Rancière; Lefébvre.

DOI: https://doi.org/10.22296/2317-1529.2016v18n3p428 


\section{INTRODUÇÃO}

Nos últimos anos, as chamadas ocupaçóes urbanas organizadas (daqui em diante apenas ocupaçôes) vêm desempenhando um papel cada vez mais relevante no cenário das dinâmicas territoriais da Regiáo Metropolitana de Belo Horizonte (RMBH), Minas Gerais (MG), e nos conflitos delas decorrentes. Trata-se da formação de assentamentos urbanos constituídos a partir da ocupação coletiva não consentida de imóveis (sobretudo de terrenos) urbanos vazios de terceiros por famílias de baixa renda para fins de moradia, estruturada previamente por movimentos sociais e assessorada por profissionais voluntários, particularmente do Direito e de Arquitetura e Urbanismo. Em linhas gerais, elas diferem de outros assentamentos precários brasileiros especialmente por partirem de uma organizaçáo heterônoma, serem contestadas desde o início, ocorrerem em áreas de alto valor de mercado pelo ordenamento territorial e receberem constante assessoria jurídica e urbanística. E vêm ganhando destaque tanto pela sua escala (são milhares de famílias distribuídas em dezenas de ocupações na $\mathrm{RMBH}$ ) quanto por construírem e articularem aspectos que, até agora, têm possibilitado a sua manutenção nas áreas, apesar das açôes judiciais em andamento (por vezes, com algumas decisões de reintegração de posse ordenadas, mas não realizadas). O processo permanente de resistência das ocupaçóes diante da mobilização da maior parte do aparelho de Estado (com exceção do Ministério Público e da Defensoria Pública) e dos proprietários dos terrenos (em muitos casos empresas ligadas ao mercado imobiliário) suscita um universo de conflitos que talvez as coloque como um dos maiores conflitos fundiários urbanos do Brasil hoje.

De acordo com seus promotores, as ocupaçôes têm por fundamento jurídico o direito social à moradia, garantido na Constituição Federal de 1988 (CF/1988). Elas representam a luta das famílias que têm esse direito negado, diante da tímida resposta estatal ao déficit habitacional na RMBH. A CF/1988 condiciona o direito de propriedade ao cumprimento de sua função social, o que, no entendimento desses movimentos, não se realiza em terrenos urbanos vazios e destinados à valorizaçáo imobiliária. De fato, grande parte das conquistas sociais previstas na Carta Constitucional não se materializou, e a própria noçáo de funçáo social da propriedade tem seu conteúdo em permanente disputa simbólica. A CF/1988, as leis de âmbito nacional voltadas para a questáo habitacional, como o Estatuto da Cidade (Lei Federal 10.257/2001), o planejamento e a gestão urbana praticados no Brasil não só não conseguiram reverter o amplo quadro de problemas urbanos das cidades, como também parecem ter contribuído para agravá-lo. A distância entre a conquista formal (direito) e os processos de segregaçáo socioterriorial (prática social) tem sido amplamente apontada no debate especializado, tendo levado a uma retomada da luta social pela efetivação de direitos (MARICATO et al., 2013; SANTOS JÚNIOR, 2007).

As ocupaçôes urbanas organizadas se diferenciam de outras formas de luta por serem, no mesmo tempo-espaço, a luta e a efetivação do direito. Elas rompem com a ordem territorial estabelecida, instituindo-se como ato e como sujeito, que só é sujeito-no-espaço como sujeito-espaço. Essa constituição litigiosa do direito como prática social se apresenta como uma poética política do território, algo que fende a ordem existente e constrói um outro mundo. Entendidas dessa forma, as ocupaçóes têm sua dimensão política - no sentido de Jacques Rancière (2005) - dada pelo fato de se constituírem como presença sensível no mundo, o que só é possível pela ruptura 
1 Poiesis, como poética, neste trabalho, é um termo empregado em seu sentido mais direto de criação. Mais que uma produção de espaço, o ato político das ocupações, tal como se propõe aqui, é uma criação de espaço - outro espaço, outro mundo (LELIS, 2015). e reconfiguração do mundo compartilhado. Instituição de espaço-mundo, remete ao conceito de espaço diferencial de Lefebvre (1970; 1991), mas a partir de uma leitura específica: o espaço diferencial como mundo dentro do mundo, como constituição efêmera e contraditória que fende o espaço abstrato da metrópole contemporânea e expóe seus limites, mas que, engendrado em seu seio, também carrega suas contradiçôes (LELIS, 2015).

Neste texto, argumentamos que entender as ocupaçóes como momento-espaço político diferencial significa caracterizar sua própria constituição como a poiesis ${ }^{l}$ essencial e perceber que o fato de seu cotidiano ser marcado por contradições, heterogeneidades e conflitos é uma expressão tanto da impossibilidade da política como ordem instituída quanto do fato de serem espaços diferenciais escavados no espaço abstrato, o que as torna espaço do que difere, do que náo difere e do conflito entre ambos. Exploramos os sentidos das ocupações, com foco em algumas das suas contradiçôes internas e externas. As questôes são discutidas com base em dois exemplos emblemáticos da RMBH: a Ocupação Dandara, de 2009, e as ocupaçóes da Região da Izidora, de 2012-2013. No intuito de ampliar as possibilidades de compreensão desses espaços, buscamos aprofundar a noção de momento-espaço político diferencial, que aproxima alguns aspectos do político em Rancière com o diferencial em Lefebvre (LELIS, 2015). Inicialmente, é feito um rápido resgate histórico, relembrando o dano histórico contra o qual as ocupações se posicionam. Em seguida, é enfocada a especificidade das ocupaçóes como constituição (espacial) política. A partir daí, buscamos explorar algumas das contradiçóes que elas apresentam e os sentidos que adquirem na dialética da polícia e da política. À guisa de conclusão, propomos que as ocupaçóes dáo ensejo a uma abertura do olhar para a cidade. Elas se inscrevem no movimento de produção-reprodução que muda e repete o cotidiano da metrópole e inscrevem o movimento que articula o pensável-impensável de um outro espaço. Com isso, elas recolocam a questáo da possibilidade do planejamento em relaçáo ao que é efetivamente político.

$\mathrm{O}$ artigo é essencialmente reflexivo. Em termos metodológicos, os dados e informaçôes que deram suporte às reflexôes provêm de textos acadêmicos, publicaçóes em jornais, redes sociais, relatos dos agentes envolvidos, audiências públicas, eventos acadêmicos e transcriçôes de entrevistas feitas por outros pesquisadores com moradores (especialmente lideranças), ativistas, assessores e promotores das ocupaçôes.

\section{ANTECEDENTES: DO DANO HISTÓRICO À CONSTITUIÇÃO LITIGIOSA DO DIREITO}

O grande marco da história do reconhecimento seletivo da propriedade fundiária no Brasil foi a Lei de Terras, de 1850. Essa lei, em um contexto escravocrata, marcado pelo latifúndio baseado na posse, instituiu a obrigatoriedade do registro para o reconhecimento da propriedade de terras, com requisitos que excluíam negros, índios, mulheres e imigrantes pobres. A Lei de Terras também instituiu no Brasil a cisão entre posse e propriedade fundiária, tornando a propriedade um fator, em si mesmo, de distinção social e poder (LELIS, 2013).

Nesse período, as principais cidades brasileiras tinham muito de sua dinâmica cotidiana sustentada pelos escravos, ao mesmo tempo que ganhava força o modelo 
da estética burguesa europeia e sua marca da ausência de pobres da cena urbana (MARICATO, 2004). As reformas urbanas do final do século XIX e início do século $\mathrm{XX}$ e os primeiros marcos regulatórios urbanos (códigos de posturas) contribuíram significativamente para a expulsão dos pobres das principais áreas da cidade. Surgiram, assim, as primeiras favelas no Rio de Janeiro, em contínuo embate com a polícia e em meio a constantes remoçôes, bem como os primeiros cortiços no Rio de Janeiro e em São Paulo (MARINS, 1998) e as primeiras favelas em Belo Horizonte (FERNANDES, 1998).

A Habitação Social entra de forma populista na agenda pública na década de 1930, no contexto de um governo totalitário (1930-1945). Esse momento inaugurou também a cisão entre discurso e prática nas políticas habitacionais, e o início da construção do mito da casa própria e da decadência da noção de aluguel como solução de moradia (MARICATO, 2004). No curto período democrático entre 1945 e 1964, no qual acontece a intensificaçáo do crescimento urbano e o processo de metropolização se torna expressivo, a lógica desenvolvimentista do governo se manteve omissa em relação à questão habitacional. A Habitação Social volta à cena pública no contexto da ditadura militar, com a criação, em 1964, do Banco Nacional da Habitação (BNH) e do Serviço Federal de Habitação e Urbanismo (SERFHAU). Nesse período, a classe média brasileira foi inserida em massa no financiamento habitacional, e as camadas mais pobres das cidades não só não foram relevantemente atendidas, como também ainda mais segregadas, expulsas pela valorização imobiliária produzida pelas intervençóes financiadas pelo $\mathrm{BNH}$.

As lutas em torno da questão habitacional e, mais amplamente, da Reforma Urbana aumentam no contexto das lutas pela redemocratização do país, que ganham força na década de 1980. A Constituição Federal da República, promulgada em 1988, ficou conhecida como "Constituiçáo Cidadã", e instituiu um conjunto de direitos sociais urbanos.

Entre os direitos sociais reconhecidos pela $\mathrm{CF} / 1988$, destacou-se o direito social à moradia. Em relação à propriedade fundiária, a constituição rompeu com o paradigma da propriedade absoluta da terra, condicionando-a ao cumprimento da sua função social. A função social da propriedade fundiária urbana é definida pelo Plano Diretor Municipal, que se tornou o instrumento básico de política urbana afirmando a soberania local de ordenação territorial da cidade. Entre as normas gerais de abrangência nacional em matéria urbanística, o Estatuto da Cidade (Lei Federal 10.257) foi aquele que consagrou o direito à cidade como princípio e regulamentou a $\mathrm{CF} / 1988$. O Estatuto da Cidade prevê instrumentos de desestímulo à manutenção de vazios urbanos com finalidade especulativa, mas com aplicação a médio e longo prazo de ociosidade.

Apesar do arcabouço jurídico favorável à realização dos direitos urbanos, as metrópoles brasileiras continuam marcadas pela desigualdade e pela segregação, mesmo após a edição do Estatuto da Cidade, e as dinâmicas imobiliárias têm tido papel preponderante na reprodução do espaço urbano. A especulação feita com os terrenos urbanos e a apropriação privada da imensa valorização imobiliária gerada por investimentos públicos nunca sofreram um controle eficaz por parte do Estado. A qualificação de função social da propriedade ficou reduzida aos mapas de zoneamento urbano, que estabelecem parâmetros de parcelamento, uso e ocupação do solo, sendo que é praticamente inexistente a aplicação dos instrumentos de combate aos vazios urbanos 
2 Para uma crítica do PMCMV, ver: Cardoso (2011; 2013), Maricato et al. (2013) e Shimbo (2012)

3 As ocupações urbanas na $\mathrm{RMBH}$ ocorrem quase totalmente em terrenos. A primeira experiência de ocupação organizada pelas Brigadas Populares, Ocupação Caracol, entretanto, ocorreu em um prédio na Zona Sul de Belo Horizonte, e durou apenas dois meses até o despejo (LOURENÇO, 2014).

4 Para uma reflexão mais aprofundada sobre a construção do problema habitacional fundiário e do seu enfrentamento no Brasil, ver: Lelis (2013).
(FERNANDES, 2008). Enquanto isso, o déficit habitacional cresce, e as políticas habitacionais são pouco expressivas em relação às faixas de renda em que o problema se concentra, ou seja, as camadas mais pobres da população. O Programa Minha Casa Minha Vida (PMCMV), criado nos últimos anos pelo Governo Federal, tem sido a ação governamental de maior escala (em número de unidades habitacionais produzidas) no enfrentamento do chamado déficit habitacional no Brasil, com produção em massa de Habitação de Interesse Social. No entanto, além de vários outros aspectos (grandes conjuntos, localização antiurbana, baixa qualidade construtiva, entre outros), tem sido apontado, de maneira recorrente, o fato de que é necessário lançar um olhar mais atento e crítico para a noçáo de "déficit habitacional", bem como para a ideia de que o problema habitacional seria resolvido com a construçáo de mais casas ${ }^{2}$. A elaboraçáo de um diagnóstico no âmbito da realizaçáo do Plano Diretor de Desenvolvimento Integrado da Regiáo Metropolitana de Belo Horizonte (PDDI/RMBH), por exemplo, demonstrou que uma grande quantidade de imóveis urbanos vazios ou subutilizados convive com um imenso déficit habitacional.

É nesse contexto que acontecem as ocupaçôes urbanas. Movimentos sociais recentes, Comissão Pastoral da Terra (CPT) e grupos de famílias em situação precária de moradia passam a se articular no sentido da luta-realização do direito à moradia. Eles partem do pressuposto de que a negação do direito à moradia, diante da manutenção de vazios urbanos destinados à valorização imobiliária, é inaceitável, haja vista o paradigma jurídico definido pela $\mathrm{CF} / 1988$. As famílias ocupam terrenos integrados à malha urbana, servidos de infraestrutura e serviços e com alto valor de mercado, e constroem aí seu espaço de moradia ${ }^{3}$. Esse ato-processo se impóe ao proprietário do terreno, ao Poder Público e à metrópole como um todo, constituindo-se como direito em ato e demonstrando a afirmaçáo de Rancière (1996a) de que não é o direito, mas o dano, o fundador da política.

Historicamente, a moradia dos pobres acontece em áreas não visadas pelo mercado, o que facilita sua manutenção consentida (seja pelo proprietário, seja pelo governo). $\mathrm{O}$ ordenamento jurídico brasileiro reconhece o direito de permanência em assentamentos constituídos dessa forma, seja através de usucapiáo (aquisição da propriedade pela posse prolongada, em área privada), seja através das formas de concessão de uso, para o caso das áreas públicas (direito de construir e habitar, que pode ser vendido a terceiros apenas para fins de moradia). Lefebvre (1969; 1999) chama a atenção para a exclusão dos pobres que a adoção da noção de "hábitat" operou na cidade no início do século XX. Para o Brasil, Maricato (2004) mostra como a legislação urbanística foi, no mesmo período, instrumento de expulsão dos pobres da cena urbana brasileira (LELIS, 2013). Nesse sentido, as favelas urbanas brasileiras se mantiveram como espaços de resistência, como espaços dos pobres na cidade. Nesse processo, a insegurança da posse tem sido uma constante, e, de fato, muitas favelas foram e continuam sendo removidas no Brasil. Na luta dos pobres pelo reconhecimento de sua moradia, a instituição das Zonas Especiais Interesse Social (ZEIS) aparece como conquista. No entanto, as ZEIS são uma resposta da ordem à luta dos pobres pela cidade, e se configuram ora como espaços de exceção - não como parte efetiva da cidade -, ora como espaços de formalização para a governança contemporânea ${ }^{4}$. Nessas áreas, de maneira especial, o conflito político pela cidade é desconstruído e suas partes são reduzidas a problemas temáticos: a necessidade da ordem, a violência, o saneamento, as áreas verdes, as escolas, as praças, entre outros. 


\section{INSTITUIÇÃO TERRITORIAL DA POLÍTICA: A CONSTITUIÇÃO LITIGIOSA DAS OCUPAÇÕES}

As ocupaçóes em estudo se diferenciam desse processo ao escolherem, intencionalmente, terrenos com alto valor de mercado, boa inserção urbana, acesso à infraestrutura e a serviços urbanos e por se constituírem de maneira não consentida.

A história das favelas no Brasil é, em sua origem, uma história marcada pelo conflito (LELIS, 2013). O caso do Cabeça de Porco (Morro da Providência) é emblemático, cuja resistência às repetidas e violentas açôes de despejo marcou os jornais da época no Rio de Janeiro (MARINS, 1998, p. 141-142):

Pode-se supor com certa segurança que já na demolição do célebre Cabeça de Porco - situado nas faldas do Morro da Providência e posto abaixo pelo prefeito Barata Ribeiro em 1893 - começaram a surgir os irônicos resultados iniciais colhidos pelo atropelo das intervençôes republicanas. A miséria e os miseráveis que haviam perdido suas habitaçôes na derrubada violenta do cortiço tinham à disposição o morro contíguo [...]. Na vizinhança do Cabeça de Porco surgia a "favela". [...] As favelas, surgidas no Rio de Janeiro quase contemporaneamente à República, inauguravam de modo exemplar o rol de frustração das elites em eliminar as convivências de habitaçôes populares e populaçóes diversas no seio da maior e mais importante cidade brasileira de então [...].

Ao apontar a contenciosidade como uma especificidade das ocupaçôes recentes, referimo-nos ao fato de que elas se posicionam a priori como embate (são já pensadas como conflito), e como um embate em relaçáo à propriedade privada da terra com fins especulativos. Assim, náo se trata de apagar ou minimizar os conflitos em torno da história das favelas no Brasil, mas de marcar a especificidade da natureza do conflito (ou do conflito como natureza) posto pelas ocupaçóes.

Elas póem em litígio o direito à cidade (para além do direito à moradia). Os terrenos vazios ocupados se tornam espaços de moradia que, conceitualmente, se caracterizam como interesse social, mas, formalmente, denunciam e rompem o interesse público formal expresso no zoneamento urbano para a área (uma vez que na $\mathrm{RMBH}$ não há zoneamento instituído de áreas vazias para habitação de interesse social e nenhum dos terrenos ocupados vinha sofrendo qualquer tipo de medida do Poder Público para compelir seus proprietários a utilizá-los). Além disso, apesar de o paradigma da função social condicionar formalmente o direito de propriedade no Brasil, a mesma legislação póe como último recurso para desestímulo dos vazios urbanos a desapropriação, e não a perda da propriedade.

Nesse sentido, as ocupaçóes rompem com o paradigma da propriedade fundiária urbana de maneira radical: ocupam o espaço da cisão entre propriedade e posse, realizando o direito social fundamental à moradia nesse espaço; instauram um mundo possível da perda de propriedade em função do não cumprimento de uma função social fática (isto é, socialmente reconhecível). Essa fenda na ordem espacial estabelecida se apresenta também como ruptura do mito da ordem territorial urbana desenhada. O paradigma da regulação urbana, sedimentado e naturalizado, estabelece que apenas o ordenamento territorial desenhado por especialistas trabalhando para o Estado é capaz de garantir a realização das funçôes sociais da cidade. As ocupações demonstram que, no entanto, a realização do direito à cidade se dá pela prática social, 
antes, além, ou contra o que pretende o planejamento e a regulaçáo urbana entendida como ordem territorial. Tal prática se realiza em nome de um dano, o dano da inexistência (ausência, invisibilidade e mudez) territorial que a reprodução da ordem planejada não cessa de causar a essa parcela (RANCIÈRE, 1996). Elas expóem a distância, em relação a si mesmas, da cidade formalmente constituída, contada e distribuída pelo Estado através do planejamento e da legislação, com a constituição e realização de uma parcela (dos) sem parcela.

Figura 1: Mapa esquemático de localização da Ocupaçâo Dandara e da Região da Izidora e sua inserção em relação a um dos principais eixos de valorização imobiliária da $\mathrm{RMBH}$

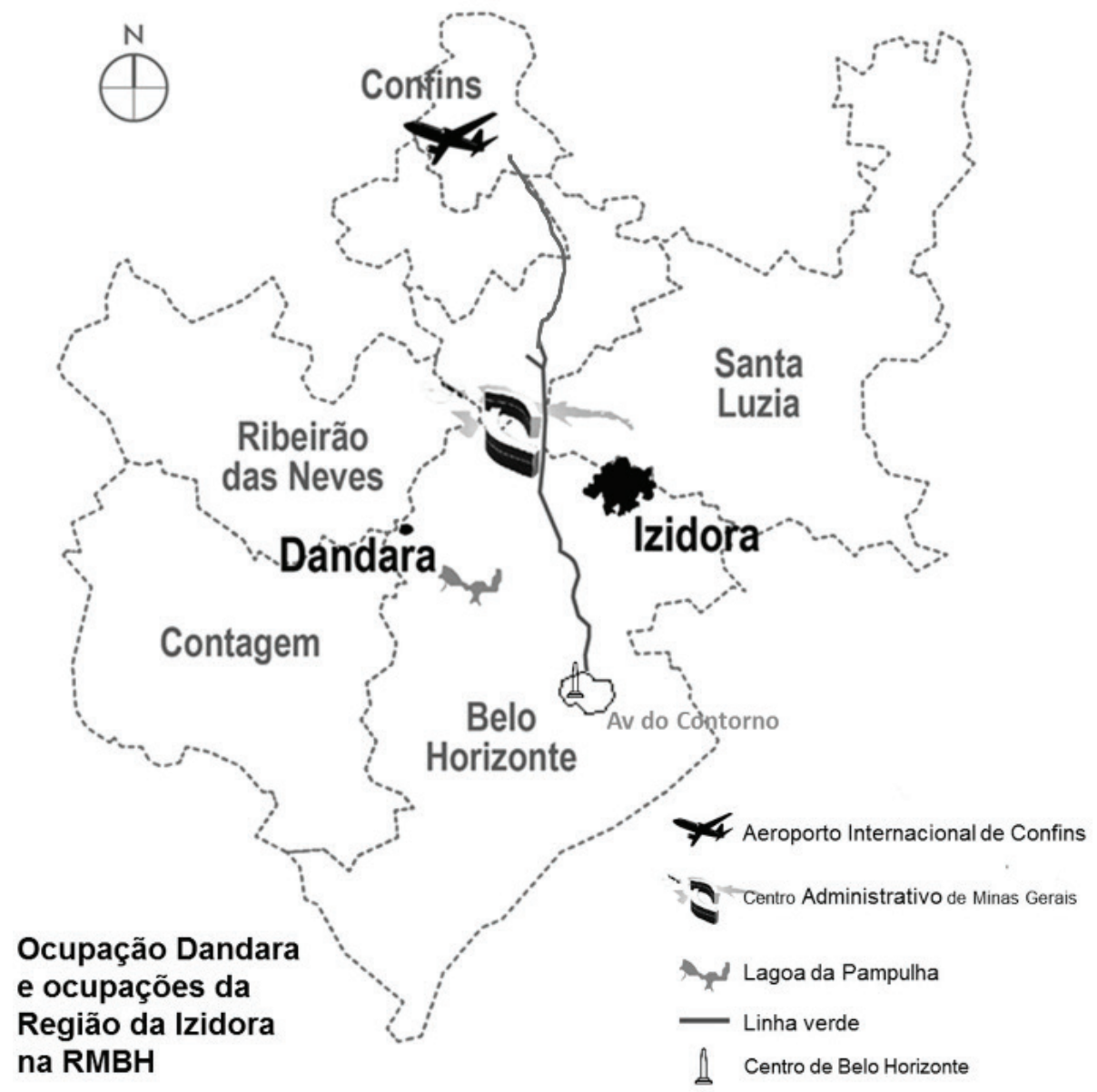

Fonte: Elaboração da autora.

A Ocupação Dandara, formada em 2009 (Figura 1), é considerada um marco nesse processo. Ela foi promovida por uma articulação entre Movimento de Luta por Moradia nos Bairros, Vilas e Favelas (MLB), Brigadas Populares, Movimento dos Sem Terra (MST) e CPT. A assessoria jurídica para preparo, realização e início do processo de resistência foi feita basicamente pelos advogados das Brigadas Populares, e o Plano Urbanístico foi elaborado como trabalho final de Graduaçáo em Arquitetura e Urbanismo por Tiago Castelo Branco Lourenço. Posteriormente, outros advogados e arquitetos se uniram para reforçar essa assessoria. A ocupação se deu em um 
terreno de propriedade de uma empresa do setor da construção civil. Atualmente, cerca de cinco mil famílias residem na área. Dandara inaugurou uma nova forma de constituição de moradia popular por meio de assessorias especializadas e redes de apoio e o seu êxito aumentou a força dos movimentos e ativistas e a mobilização de famílias para formar outras ocupaçóes.

As ocupaçóes da Região da Izidora (Figura 1), iniciadas entre 2012 e 2013, acontecem em uma área de dimensóes significativas (maior que a área urbana original de Belo Horizonte, compreendida na Avenida do Contorno), de propriedade privada, localizada na divisa de Belo Horizonte com Sabará. Nessa área, há um sanatório desativado, uma comunidade quilombola, uma rica rede hídrica e uma grande área vegetada. Ela tem essa mesma configuração há décadas e estava destinada à preservação ambiental no zoneamento municipal, com restriçóes quanto ao parcelamento, uso e ocupação do solo. Nos últimos anos, houve investimentos de escala metropolitana - eixos viários, criação de um Centro Administrativo Estadual, ampliação do Aeroporto Internacional de Confins, representados esquematicamente na Figura 1 - que aumentaram bastante o valor de mercado da terra dessa regiáo.

A Região da Izidora, por sua localização, configuração (dimensão, recursos ambientais), aspectos históricos e inserção urbana (acesso a infraestrutura, equipamentos e serviços), tem uma presença significativamente mais expressiva que a região da Ocupação Dandara do ponto de vista das dinâmicas metropolitanas e também sofreu um impacto maior em relação à valorização imobiliária, decorrente dos investimentos nos últimos anos no chamado Vetor Norte da RMBH. O terreno onde se formou a Ocupação Dandara já era de propriedade de uma construtora, e o projeto previsto para a área, investimento em produçáo de moradias com recursos do Programa Minha Casa Minha Vida, não envolvia a aplicação de instrumentos urbanísticos tâo complexos como no caso da Região da Izidora.

Em 2010, foi aprovada uma Operação Urbana Consorciada no terreno, que permitia a alteração do zoneamento para a realizaçáo de um grande empreendimento imobiliário (13.400 unidades habitacionais, mais equipamentos urbanos), destinado à Habitação de Interesse Social. A notícia da mudança de zoneamento com finalidade de construir habitação de interesse social chamou a atenção de movimentos sociais por moradia e de grupos de famílias em situação precária de moradia. A área passou a ser ocupada através de processos inicialmente autopromovidos, que logo se articularam aos movimentos e ativistas que vêm promovendo as ocupações urbanas organizadas na RMBH. As ocupaçôes na Região da Izidora atualmente são três, Rosa Leâo, Vitória e Esperança, e, de acordo com estimativas das lideranças, somam aproximadamentee oito mil famílias. Elas vivem em processo permanente de resistência a ameaças de despejo e contam com a assessoria, também permanente, de profissionais especializados, como advogados populares e arquitetos e urbanistas ligados às principais universidades locais e aos Arquitetos Sem Fronteiras, além do trabalho do Ministério Público (Promotoria de Direitos Humanos), da Defensoria Pública e de uma ampla rede de apoiadores. Os moradores das ocupaçóes sofrem todo tipo de ameaças, violências simbólicas e segregaçáo por parte dos proprietários do terreno, do Poder Público estadual e municipal (são recusados pelos postos de saúde e creches, não recebem ambulância, têm acesso dificultado à água tratada e energia elétrica e não têm acesso à rede pública de coleta de esgoto).

A instituição territorial do sujeito político coletivo chamado ocupação urbana 
- a poética territorial - irrompe no mundo sensível da metrópole, pondo no centro da cena urbana os restos da ordem sistematicamente tornados invisíveis pela ação do Estado através do planejamento e da legislação. Ela se torna particularmente importante porque acontece em um contexto em que os processos de financeirização do capital imobiliário são intensificados (FIX, 2007; SHIMBO, 2012). A legislação brasileira tem-se direcionado para a financeirização dos empreendimentos imobiliários e para a maior segurança jurídica dos títulos emitidos em tais negócios. Essa política de estabelecer condições para a criação e ampliação da atuação do capital financeiro global nas dinâmicas imobiliárias metropolitanas está relacionada com a posição que o Brasil tenta ocupar no cenário geopolítico mundial e com a forma que essa posição o insere nas relaçôes macroeconômicas globais (MAGALHÂES; SILVA; TONUCCI FILHO, 2011; VAINER, 2000). A existência e a resistência das ocupaçôes demonstram a fragilidade dessa segurança produzida no âmbito formal para a reprodução ampliada do capital global, solapada pela instalaçáo de um território dos excluídos da cidade precisamente onde a cidade quer fazê-los invisíveis e se vender como investimento seguro e rentável. Isso faz com que as ocupaçóes se instituam como sujeito não apenas na cena urbana, mas também no seu centro, "colocando o dedo na ferida" da função social da propriedade urbana. A ausência de controle da manutenção especulativa de vazios urbanos e a timidez da política habitacional produzem a fissura mais impensada e impensável no projeto não dito do Estado de financeirização da cidade.

Essa é uma das dimensōes indizíveis das ocupaçôes. Quando o Poder Público ajuda a construir e sustenta a percepção desse fenômeno como um conflito privado entre proprietários e ocupantes, ele reforça o discurso moral da indignação diante da ambição do capital e dissimula a sua omissáo no papel de garantir o cumprimento da função social da propriedade e de prover habitação social. A razão de ser da empresa capitalista é a reproduçáo ampliada do capital, o papel do Estado é precisamente o de mediar o interesse público e o interesse privado, garantindo, ao mesmo tempo, as condiçôes dessa reprodução e impondo-lhe limites em nome do interesse da coletividade. A ilegalidade da retenção especulativa tem, em sua essência, a contribuição dos governos municipal, estadual e federal, que não cumprem com a obrigação constitucional de qualificar e fazer cumprir a funçáo social da propriedade privada urbana. Contradição do espaço abstrato, na qual o diferencial se constrói: o mesmo planejamento urbano que busca estruturar a cidade em função da reprodução ampliada do capital produz os problemas que ameaçam a realização desse objetivo.

As ocupaçôes da Regiấo da Izidora expressam isso. É preciso observar que: (I) a incorporadora do terreno no projeto de Operaçáo Urbana Consorciada na área é uma empresa de capital aberto e tem tentado chamar a atenção dos investidores internacionais; e (II) é a empresa que de alguma forma se senta à mesa de negociação, por mais questionáveis que sejam suas propostas. A realizaçáo do despejo, violento e possivelmente com vítimas fatais, de uma ocupação que mobiliza atençôes nacionais e internacionais seria péssima para a imagem da empresa no mercado global. A empresa tenta encontrar uma solução que, por um lado, não comprometa significativamente o retorno esperado do investimento e, por outro, ofereça uma alternativa que as famílias da ocupação aceitem, dando um fim ao conflito fundiário urbano posto. Linha essa que ainda não conseguiram traçar. Ao mesmo tempo, o município tem-se mantido inatingível formalmente, e sua responsabilidade no conflito não tem sido demonstrada - isto é, ainda não foi possível estabelecer formalmente as obrigaçóes 
do Município de Belo Horizonte em relação ao conflito. O mesmo pode ser dito para o governo estadual, que permanece na posiçáo de, por liberalidade, criar uma mesa de negociação e ao redor dela se sentar, sem apresentar, porém, uma resposta própria. Esse conflito ameaça a "atração de investimentos" almejada pelos governos municipal e estadual: um desdobramento violento traria consequências diretas e imediatas à empresa incorporadora, criaria uma imagem de insegurança para o investimento imobiliário de outras empresas semelhantes e de outros investidores.

O problema público da habitação de interesse social e da retenção especulativa de imóveis diante da questão habitacional, algo que os governos tentam privatizar de todas as maneiras nos casos das ocupaçôes, retorna à dimensão pública com uma força considerável.

\section{ESPAÇOS DIFERENCIAIS CONTRADITÓRIOS - O QUE DIFERE, O QUE NÃO DIFERE}

Conforme apontado, entender as ocupaçóes como momentos-espaços políticos diferenciais escavados na ordem socioterritorial dada pelo espaço abstrato permite, como contribuição, a exploração de suas contradiçôes, sem que isso implique uma redução de seu caráter de ruptura.

\section{DIFERENÇA E DISTINÇÃo}

$\mathrm{Na}$ disputa pela representação social de legitimidade, os promotores da ocupação realizam operaçóes conceituais de relevante peso simbólico, que, de fato, têm sido eficazes na construção dessa representação. A representação é a ideia de legalidade do fenômeno, cujos efeitos são a mobilização de mais apoiadores, o maior recrutamento de famílias e uma pressão pela interpretação jurídica a favor da permanência das ocupaçôes nas áreas. No entanto, essa identidade das ocupaçôes opera a partir da criação de fronteiras simbólicas entre um eu e um náo-eu, as quais separam, marginalizam, inferiorizam e deslegitimam outras formas de constituição de assentamentos para moradia de famílias pobres. Lefebvre (1970) aponta alguns problemas decorrentes da substituição da diferença pela distinção ou da ênfase na criação de distinçóes que excluem, reduzem ou invisibilizam a diferença:

Cuando la burguesía europea quiso obtener de la 'distinción, en el siglo XIX, un método de pensamiento y de vida, una ética y una estética, lo único que supo hacer fue imitar a la aristocracia 'distinguida' naturalmente. En su acepción más favorable, la palabra 'distinción' define las cualidades que se atribuye la clase dominante y que no tiene de manera espontánea, que adquiere con una aplicación que las desmiente. Es una denominación elitista que no tiene nada que ver con lo diferencial y las diferencias (LEFEBVRE, 1970, p. 44).

Além disso, essas distinções podem ainda reduzir a percepção do caráter político essencial das ocupaçôes, enfraquecendo seus universos de possibilidades. Esses discursos sobre as ocupaçôes operam a partir da lógica e dentro das possibilidades oferecidas pela ordem (polícia), recortando o visível de forma a inserir as ocupaçóes de maneira mais favorável na ordem, mas sem de fato alterá-la. Entre essas distinçôes, 
merecem destaque as que têm sido feitas entre (a) ocupação e invasão, (b) ocupação e favela e (c) ocupaçôes e loteamentos (irregulares).

\section{OCUPAÇÃo E INVASÃo}

De acordo com os promotores das ocupaçóes, é importante fazer essa separação, uma vez que a invasão remete a uma tomada hostil, injusta e violenta daquilo que é do outro. Já ocupação remete ao ato pacífico de dar destino a algo que está sem uso, no caso em questão, dar uma função social a um imóvel vazio, fazendo cumprir o direito constitucional à moradia.

O ponto mais interessante da construção dessa distinção é que ela dissimula o que é o cerne do caráter político das ocupaçóes, aquilo que as constitui como espaços diferenciais - a radicalidade da sua poética. Trata-se de uma presença que é imposta. Ainda que não o faça de maneira explicitamente violenta, com o uso de armas, ela se impóe simbolicamente através do uso de estratégias previamente definidas para viabilizar seu objetivo: o início na madrugada, o grande número de pessoas, a mobilização de apoio nas redes sociais e a mobilização do discurso da legitimidade jurídica. Ela se impôe, nos termos de Rancière, como alteração (na percepção) do mundo compartilhado.

As ocupaçóes invadem. Invadem o mundo compartilhado. Invadem o terreno dos outros que estava lá como expectativa de lucro. Invadem a vizinhança como diferença entre os que lutam e os que se sujeitam. Invadem a ordem socioespacial criada e protegida pela regulação urbana. Invadem o ordenamento jurídico. Não há legalidade presumida com o estabelecimento de qual é a função social de uma propriedade e realizá-la com as próprias mãos. Náo há legalidade presumida com o início um parcelamento do solo sem projeto aprovado. E é porque invadem que as ocupaçôes se estabelecem como um mundo diferente e da diferença, espaço do que não tem espaço, parcela dos que não têm parcela.

A contradição posta pela operação conceitual que busca legitimar as ocupações é a tentativa de ancorá-las no mundo existente e socialmente aceitável, dissimulando o fato de que elas rompem com esse mundo. Transforma o que difere no que náo difere. É uma contradição especialmente em relação ao discurso mais amplo dos movimentos sociais promotores, com seus objetivos declarados de enfrentar o status quo e sua ancoragem nos preceitos da esquerda revolucionária.

\section{OCUPAÇÃo E FAVELA}

A distinção que tem sido feita entre ocupação e favela se apoia no fato de que as favelas são espontâneas e as ocupações são organizadas, tanto no sentido da prática do ato de ocupar o espaço quanto nas formas pelas quais essa prática se configura no território.

Uma avaliação baseada nos parâmetros utilizados no cenário global para caracterizar slum (DAVIS, 2006), que no Brasil é traduzido como "favela", aponta para muitas semelhanças objetivas entre "favela" e "ocupação". Os critérios frequentemente utilizados são a insegurança de posse, a baixa renda dos moradores, a falta de infraestrutura e serviços urbanos, a baixa qualidade da unidade habitacional, caracterizada em função do nível de habitabilidade, salubridade e segurança. No Brasil, particularmente em Minas Gerais, a expressão ocupação espontânea vinha sendo 
usada para diferenciar os assentamentos formados por iniciativa dos próprios moradores daqueles que decorriam de venda ou doação de lotes (irregulares) a partir de um loteador. Essas ocupaçōes "espontâneas" se deram, por vezes, de forma bastante organizada, com criação de estratégias de resistência em momentos de maior insegurança da posse e, em alguns casos, com decisóes compartilhadas entre os moradores quanto ao tamanho e a distribuição dos "lotes".

A operação conceitual de distinção realizada pelos promotores das ocupaçóes busca distingui-las das favelas em razão da percepção negativa que a sociedade tem destas últimas. Essa distinção cria também uma hierarquia e contribui para o aprofundamento do estigma social em torno das favelas, ao mesmo tempo que dissimula e repete uma distinção tecnocrática: a assessoria de especialistas. Ela acontece em dois momentos: (a) no momento inicial, em que a auto-organização dos moradores para a construção de uma favela é reduzida a espontaneidade, enquanto a hetero-organização na construção das ocupações é vista simplesmente como "organização"; e (b) no ordenamento territorial definido pelo plano urbano seguido pelas ocupaçóes, o qual, no caso das favelas, ou náo existe ou não é feito por especialistas. $\mathrm{O}$ peso social dessa distinção remete, de um lado, ao idílio da vida digna, formatado aos moldes do imaginário moderno, e, de outro, à noção, que sempre permeou o urbanismo, de que a ordem territorial produz a ordem social. A forma como as ocupaçôes consolidam essas duas distinçóes marca nelas a continuidade de paradigmas da ordem, do espaço abstrato, do que não difere.

$\mathrm{Na}$ escala metropolitana, conforme apontado anteriormente, as ocupaçôes se distinguem das favelas pela sua localização urbana e pelo embate sistemático com a retenção especulativa da propriedade da terra. Aqui, mais uma vez, a distinção acaba por achatar o caráter político das ocupaçôes, que reside no que elas têm não de distinção, mas de diferencial: a tomada deliberada de uma área estratégica.

\section{OCUPAÇÕES E LOTEAMENTOS (PERIFÉRICOS)}

Os loteamentos irregulares que configuram as periferias urbanas pobres têm sido caracterizados pelo governo estadual de Minas Gerais como decorrentes da iniciativa de loteadores. O loteador geralmente é um agente externo, privado ou o próprio Poder Público. Os assentamentos constituídos dessa forma foram uma alternativa significativa de moradia para os trabalhadores dos grandes centros urbanos brasileiros e tiveram um papel expressivo no processo de metropolização. Os loteamentos clandestinos são formados a partir de projetos informais de parcelamentos, popularmente conhecidos como plantas particulares, e adquiridos pelos moradores através de contratos também informais. Os projetos de parcelamento lhes dão uma certa regularidade de traçado que os diferencia visualmente das favelas e aproxima-os do desenho dos loteamentos regulares - traçado viário, organização de lotes e quadras.

As ocupaçóes urbanas organizadas também seguem o ordenamento territorial de um plano urbano náo aprovado pelo município. No entanto, elas entram em um explícito embate com a propriedade do terreno em que ocorrem. Como esse processo não envolve a compra da terra pelos moradores, estes não escolhem o terreno de acordo com suas condições de pagamento, mas pela inserção urbana.

Assim, o embate com a propriedade privada absoluta da terra urbana diferencia as ocupaçóes de outras formas de loteamentos irregulares, enquanto a existência de um 
projeto de parcelamento, que não é aprovado, mas orienta a configuração do território, aproxima as duas formas de constituição de assentamento. Esse ordenamento territorial não tem impedido a precariedade de diversos tipos de loteamentos irregulares. Há o risco de que a precariedade que necessariamente marca os primeiros anos de uma ocupação, pela negação do Poder Público de prover infraestrutura e serviços urbanos, combinada com a baixa renda dos moradores, as aproxime ainda mais dos loteamentos irregulares e continue separando-as do direito à cidade que tanto buscam realizar.

\section{AUTONOMIA E HETERONOMIA: PROJETO DOS POBRES E PROJETOS PARA OS POBRES}

A relação entre o habitus do especialista ao pensar, planejar e desenhar espaços e o habitus dos moradores das ocupaçóes é atravessada por contradiçóes e por conflitos, muitas vezes velados ou dissimulados.

Em primeiro lugar, o sujeito genérico "morador da ocupação" só pode ser definido como sujeito político de seu ato - a "origem" dos moradores das ocupações não é homogênea, eles podem ser entendidos como, em sua maioria, provenientes da "ralé estrutural" e, em menor parte, dos "batalhadores", como aponta Lourenço (2014), utilizando a terminologia de Jessé Souza. Nesse caso, é importante ter em mente que há diferenças estruturais centrais entre essas duas categorias, no que se refere a seus modos de disposição, bem como à sua posição na distribuição dos papéis sociais na reprodução da realidade brasileira. Além disso, há moradores que não poderiam, a rigor, ser enquadrados nessas categorias. $\mathrm{O}$ ato de constituição do sujeito político morador da ocupação rompe com as predisposiçôes dessas categorias e as une como o pobre ou o povo, no sentido dado por Rancière. Esse "novo" sujeito carrega e rompe com as predeterminaçóes, inaugurando uma presença onde ela não deveria existir, ainda que leve consigo suas contradiçóes. Lourenço (2014) expóe alguns aspectos dessa heterogeneidade e demonstra que náo se pode pensar em um bloco ou em um modelo ou versão pobre, e eventualmente politizada, do "homem universal", conhecido, de longa data, por arquitetos e urbanistas.

Em segundo lugar, a insistência dos moradores das ocupaçóes em uma configuração do território baseada na parcela (lote) individual unifamiliar tem sido ponto de conflitos, que podem se mostrar mais velados ou mais explícitos na constituição desses espaços. Ela é uma das dimensôes do conflito entre a construção de um mundo comum, estruturado a partir de práticas de comunidade diferentes daquelas que são hegemônicas na metrópole em que se inserem, e as práticas que de fato se configuram na vida das ocupaçóes.

Em relação aos moradores, há que ter em mente que não se trata de uma proposta revolucionária, mas de acreditar na e viver a ocupação como forma de partilhar o mundo comum, cuja parte lhes é negada: o mundo da vida privada estruturada em torno da propriedade privada de uma "moradia digna". O principal ponto de ruptura, o ato poético-político inaugural que a ocupação realiza, é a sua própria constituição, expondo e ocupando a cisão na ordem do mundo (da propriedade privada) para fazer parte dele. Muito da luta cotidiana dos moradores consiste em realizar sua inserção social, lutando contra as diversas formas de sofrimento às quais são expostos todos os dias, quando a sociedade lhes diz que não os reconhece como parte dela, em razão da forma como tentaram se integrar. A recusa do atendimento pelos serviços públicos de 
saúde e a segregação que essas pessoas sofrem pelos moradores do entorno lhes fazem lembrar que o seu ato político ainda está em curso. A fala repetida por moradores das ocupações - "Nós somos trabalhadores e trabalhadoras honestos" - indica essa necessidade de reconhecimento social como iguais, não como diferentes. Eles precisam articular sua manutençáo na terra e no mundo moderno do trabalho ao mesmo tempo, o que torna a luta ainda mais dura. Nesse processo, também precisam articular o discurso de crítica e mudança social dos movimentos e ativistas que os apoiam com seus próprios anseios de partilhar dessa mesma sociedade criticada. Enquanto para os movimentos e ativistas sociais as ocupações são uma forma de mudar o mundo e abrem um universo de possibilidades para construir um mundo diferente, pautado na noção de comum, para os moradores elas sáo uma forma de participar do mundo em condiçóes de igualdade, de construir seu lugar no mundo.

Apesar da crítica aos anseios dos moradores pela propriedade privada individual, os promotores das ocupaçóes mobilizam esses mesmos anseios para recrutar moradores, através de cartazes com frases como "Venha lutar pela casa própria!" ou "Saia da cruz do aluguel”. Há uma aposta na ideia de que o processo de formação política pela vida nas ocupaçóes, conduzido pelos movimentos sociais, engendre uma consciência crítica ampliada em relação ao status quo e uma apropriação por parte dos moradores da leitura de mundo que os promotores carregam. Há uma contradição no fato de que os promotores almejam a consciência crítica e a emancipação dos moradores adotando, como meio para esse fim, uma estrutura de organização heterônoma e hierarquizada e entendendo como emancipação a apropriação do outro de seus ideais de emancipação.

A contradição entre incentivar a construçáo de pensamento crítico e difundir o seu pensamento crítico tem uma base na diferença de classe entre promotores e moradores das ocupaçôes, conforme argumenta Lourenço (2014). E ela tem também um componente ligado às especificidades do ser social construído pelo campo da Arquitetura e Urbanismo e pelo campo do Direito. O habitus desses profissionais, no sentido dado ao termo por Bourdieu (1983), tem um papel fundamental no fato de que as contradiçóes de classe expressas nos conflitos referidos são especificamente estas e não outras.

A tendência para um pensamento institucionalizante, o papel de destaque para a estruturação dos discursos, as operaçôes conceituais mobilizadas e a interpretação da prática social pela mediação do Direito são características conhecidas do campo jurídico, bem como a naturalização do falar em nome do outro e de definir para esse outro as melhores estratégias, centradas na ideia de eficácia. Por sua vez, o pensamento espacial pautado na noçáo de ordem e ordenação, o destaque para o critério de eficiência e a formulação de respostas espaciais a serem apresentadas, semiprontas, para avaliação são características comuns dos arquitetos. Esses aspectos nos lembram que arquitetos e advogados populares são, primeiramente, arquitetos e advogados.

Algumas dessas questôes podem ser observadas no que se refere ao plano urbano mencionado anteriormente, que atua como estruturador da configuração das ocupaçóes. Plano urbano aqui é basicamente um desenho. Esse desenho, no caso das ocupaçôes, é semelhante a um esboço de um projeto de loteamento, produto usual na prática cotidiana do urbanismo. É produzido - desenhado - por um arquiteto-urbanista. No entanto, o processo de produçáo desse plano se configura como processo de planejamento, em que lideranças dos movimentos, coordenadores das ocupaçôes, arquitetos-urbanistas, advogados e jovens profissionais e pesquisadores ativistas se envolvem e discutem como 
5 Lourenço aponta as relações dos movimentos sociais e ativistas que compõem os grupos promotores das ocupações com a tradição da esquerda marxista brasileira (LOURENÇO, 2014).

6 Para uma análise mais aprofundada da noção de construção do comum a partir de Hard e Negri e como as ocupações apontariam para a possibilidade dessa construção, conferir, entre outros, Mayer (2015), Alves (2015) e Tonucci Filho (2015). cada recorte de espaço estrutura a ocupaçáo como mundo desejado. Esse papel pedagógico da configuração do espaço expressa a antiga crença na ideia de que determinada ordem espacial produz determinada ordem social, ainda que aqui os ideais em jogo sejam fortemente influenciados por concepçóes-projetos-de-mundo de inspiração marxiana e/ ou por questôes mais recentemente discutidas sobre a constituição do comum ${ }^{6}$.

No entanto, a atuação desses profissionais na ocupação traz uma inversão fundamental, a qual subverte os lugares que esses campos ocupam na reprodução social. Pondo seu trabalho a serviço dos moradores das ocupações, eles demonstram que, ainda que a lógica operativa da profissão não se altere, a inversão do "cliente" transforma as estratégias jurídicas e urbanísticas, historicamente usadas para opressão e para exclusão dos pobres, em suas próprias armas para lutar contra isso.

O processo não é simples. A ciência moderna tem seu papel muito mais associado à reproduçáo do status quo que à transformaçáo dele (LELIS, 2007). Faltam à Arquitetura e Urbanismo e ao Direito métodos, conceitos e instrumentos específicos para que exerçam um papel de contribuição na construção coletiva de mudança social, como conclui Lourenço (2014). O trabalho dos assessores das ocupaçóes torna-se, nesse sentido, uma luta política pela construção de um lugar diferente para eles próprios.

A instituição das ocupações como sujeito capaz de dialogar com a ordem em seus mesmos termos, mas contra ela, inverte os sentidos do discurso especializado e os lugares dos agentes sociais nesse debate - pondo os moradores em posição igual de fala a partir dos códigos operados naquilo que é dito.

A lógica vertical e heterônoma da atuação técnica nas ocupaçôes não as esvazia de política nem retira delas aquilo que as difere. A articulação dos pensáveis-impensáveis do cotidiano da assessoria pode também funcionar como um processo de formação crítica não apenas para os moradores, mas também para os próprios profissionais. Além disso, é com a sua atuação, carregada de contradições, que as ocupações se constituem como espaços diferenciais.

\section{CONSIDERAÇÕES FINAIS}

As ocupaçóes urbanas são um universo riquíssimo. Elas se apresentam como um microcosmo do embate entre as forças homegeneizantes e as capacidades diferenciais (LEFEBVRE, 1970). Como tal, desafiam o pensamento linear e exigem formas mais dialéticas de aproximação, bem como olhares que sempre se percebam incompletos.

A forma como esse tempo-espaço se constitui como sujeito político e as rupturas e continuidades que opera no mundo partilhado não se deixam entender por apenas um mergulho no cotidiano, pela análise do território, pela inserção urbana, nem pela ordem global, isoladamente. A tentativa de aproximação teórica dessa complexidade pode contribuir para pensar o espaço diferencial como espaço-tempo aqui e hoje. Nesse sentido, elas suscitam questôes para o pensamento e a prática do urbanismo e do planejamento urbano contemporâneos.

No processo de construçáo e na vida das ocupaçôes, um novo habitus se estrutura, e se estrutura tanto mais à medida que a ocupaçáo tende a se tornar polícia e a diminuir sua força como diferença. É em torno desse novo habitus e de seu espaçomundo que se podem pensar as contradiçóes ligadas ao pensamento e à pratica do urbanismo e do planejamento urbano. 
Os conflitos em torno da distribuição das famílias em "lotes individuais" ou "lotes coletivos", como exposto anteriormente, são exemplos da relação complexa entre o desenho (a representaçáo abstrata) e os vários processos de planejamento que ele encerra. O lugar privilegiado do discurso competente faz ecoar aqui, tanto no processo quanto no produto, o caráter militar do planejamento - instrumento através do qual um sujeito tem a visão global do espaço-objeto sobre o qual ele vai lançar suas açôes com vistas a um determinado fim. Nesse sentido, as questôes que as ocupaçôes trazem para o planejamento urbano e o urbanismo não se põem em termos de o melhor lugar para cada tipo de especialista, ou se elas seriam mais eficazes ou menos eficazes se se produzissem longos planos de desenvolvimento por arquitetos, urbanistas, geógrafos, economistas, advogados ou outros, ou quem deveria coordená-los, ou se esse desenho estruturante indicaria um reinado do arquiteto nelas. Elas provocam um questionamento sobre a natureza dessas atividades, sobre seus sujeitos, sobre seus métodos e instrumentos. O planejamento para o político, nesse caso, torna-se, ao mesmo tempo, uma condição e uma impossibilidade: por um lado, a criação de estratégias para a formação de uma nova ocupação ou para o seu fortalecimento tem-se mostrado essencial para o seu êxito (permanência na área), bem como a estruturação de um desenho tem sido uma estratégia importante para a inserção simbólica das ocupaçôes no mundo da cidade. Por outro, a constituição do sujeito (morador da) ocupaçáo, ao ser, igualmente, a constituiçáo do (sujeito do) espaço, foge ao controle prévio do mundo idealizado pelos promotores, embora, em alguma medida, se tenha tentado que esse desenho simbolizasse um pacto social construído coletivamente.

Ao romperem com o mito da ordem territorial desenhada e realizarem-se como direito em ato, as ocupaçóes trazem ao planejamento e ao urbanismo a mesma questão que Lefebvre fez para o Direito em seu Manifesto Diferencialista (1970): de que maneira os planejadores e urbanistas se inserem de fato na prática social? Há que se construir, ainda e sempre, uma prática política nos processos de pensamento, planejamento, desenho e construção do espaço. Afinal, cada poética política não é senão uma invenção?

\section{REFERÊNCIAS}

ALVES, R. O. Entre a desposessão e a apropriação, o direito à cidade: quando o comum é possível. 2015. Tese (Doutorado em Geografia) - Instituto de Geociências, Universidade Federal de Minas Gerais, Belo Horizonte, 2015.

BOURDIEU, P. Razóes práticas. São Paulo: Ática,1983.

CARDOSO, A. L. Habitação social no Brasil: política ou mercado? Reflexôes sobre a construção do espaço metropolitano. In: ENCONTRO NACIONAL DA ANPUR, 14, 2011, Rio de Janeiro. Anais... Rio de Janeiro: ANPUR, 2011. Disponível em: <http:// unuhospedagem.com.br/revista/rbeur/index.php/anais/article/view/3082>. Acesso em: 13 jun. 2015.

(Org.). O Programa Minha Casa Minha Vida e seus efeitos territoriais. Rio de Janeiro: Letra Capital, 2013.

DAVIS, M. Planeta favela. São Paulo: Boitempo Editorial, 2006.

FERNANDES, E. A regularização de favelas no Brasil: o caso de Belo Horizonte. In: (Org.) Direito Urbanistico. Belo Horizonte: Del Rey, 1998. p. 136-167.

Reforma urbana e reforma jurídica no Brasil: duas questóes para reflexão. In:
Natália Lelis é arquiteta e urbanista pela Universidade Federal de Viçosa (UFV); mestra em Arquitetura e Urbanismo pela Universidade Federal de Minas Gerais (UFMG); doutoranda em Geografia pela UFMG. E-mail:natilelis@gmail.com

Artigo recebido em 10 de maio de 2016 e aprovado para publicação em 21 de setembro de 2016. 
COSTA, G. M.; MENDONÇA, J. G. (Org.). Planejamento urbano no Brasil: trajetória, avanços e perspectivas, Belo Horizonte, C/Arte, 2008. p. 123-135.

FIX, M. São Paulo cidade global: fundamentos financeiros de uma miragem. Sáo Paulo: Boitempo Editorial, 2007.

LEFEBVRE, H. O direito à cidade. São Paulo: Documentos, 1969. El manifiesto diferencialista. 2. ed. México: Siglo Veinteuno Editores, 1970. . The production of space. Oxford: Blackwell Publishing, 1991. A revolução urbana. Belo Horizonte: Ed. UFMG,1999.

LELIS, N. Por uma teoria instável: pensamento e não pensamento em arquitetura e o caso de Bernard Tschumi. 2007. Dissertação (Mestrado em Arquitetura e Urbanismo) - Escola de Arquitetura, Universidade Federal de Minas Gerais, Belo Horizonte, 2007. . Regularização, regulação e o Estado: entre a política e a polícia. In: ENCONTRO NACIONAL DA ANPUR, 15., 2013, Recife. Anais... Recife: ANPUR, 2013. Do momento-espaço político: o momento político e o espaço diferencial. In: COSTA, G. M.; COSTA, H. S. M.; MONTE-MÓR, R. (Org.). Teorias e práticas urbanas: condiçôes para a sociedade urbana. Belo Horizonte: C/Arte, 2015. p. 297-316.

LOURENÇO, T. C. B. A cidade ocupada. 2014. Dissertação (Mestrado em Arquitetura e Urbanismo) - Escola de Arquitetura, Universidade Federal de Minas Gerais, Belo Horizonte, 2014.

MAYER, J. G. B. O comum no horizonte da metrópole biopolítica. 2015. Dissertação. (Mestrado em Arquitetura e Urbanismo) - Escola de Arquitetura e Urbanismo, Universidade Federal de Minas Gerais, Belo Horizonte, 2015.

MAGALHÂES, F.; SILVA, H.; TONUCCI FILHO, J. B. M. Valorização imobiliária e produção do espaço: novas frentes na RMBH. In: COSTA, H. S. M.; MENDONÇA, J. G. (Org.). Estado e capital imobiliário: convergências atuais na produção do espaço urbano brasileiro. Belo Horizonte: C/Arte, 2011. p. 17-40.

MARICATO, E. Habitação e Cidade. São Paulo: Atual, 2004

et al. Cidades rebeldes: passe livre e as manifestaçôes que tomaram as ruas do Brasil. São Paulo: Boitempo, Carta Maior, 2013.

MARINS, P. C. G. Habitação e vizinhança: limites da privacidade no surgimento das metrópoles brasileiras. In: SEVCENKO, N. (Org.). História da vida privada no Brasil. São Paulo: Companhia das Letras. 1998. p. 131-170. v. 3.

MARTINS, J. S. O cativeiro da terra. 9. ed. São Paulo: Contexto, 2010.

RANCIÈRE, J. O desentendimento: política e filosofia. São Paulo: Ed. 34,1996a.

. O dissenso. In: NOVAES, A. (Org.). A crise da razão. São Paulo: Companhia das Letras, 1996b. p. 367-382.

. A partilha do sensivel: estética e política. São Paulo: Ed. 34, EXO experimental org., 2005.

O ódio à democracia. São Paulo: Boitempo Editorial, 2014.

SHIMBO. L. Habitaçâo social de mercado: a confluência entre Estado, empresas construtoras e capital financeiro. Belo Horizonte: C/Arte, 2012.

SANTOS JÚNIOR, O. A. Cidade, cidadania e planejamento urbano: desafios na perspectiva da reforma urbana. In: FELDMAN, S.; FERNANDES, A. (Org.). O urbano e o regional no Brasil contemporâneo. Salvador: EDUFBA, 2007. p. 293-314.

TONUCCI FILHO, J. B. M. Urban occupations as urban commons? Explorations from Belo Horizonte, Brasil. In: IASC THEMATIC CONFERENCE, 1., 2015, Bologna. Annals... Bolonha: IASC, 2015.

VAINER, C. Pátria, empresa e mercadoria. In: ARANTES, O.; MARICATO, E.; VAINER, C. A Cidade do Pensamento Único: desmanchando consensos. Petrópolis: Vozes, 2000. p. $75-103$. 